\title{
Dividend Policy, Economic Value Added, Market $\beta$, Firm Size and Stock Return
}

\author{
Dwi Asih Surjandari ${ }^{1} \&$ Lela Nurlaela Wati ${ }^{2}$ \\ ${ }^{1}$ Assistance Professor of Accounting department of Universitas Mercubuana, Jakarta \\ ${ }^{2}$ Associate Professor of Sekolah Tinggi Ilmu Ekonomi Muhammadiyah, Jakarta \\ Correspondence: Dwi Asih Surjandari Accounting Department, Universitas Mercubuana, Jakarta, Indonesia.
}

Received: July 8, 2020

Accepted: August 14, 2020

Online Published: August 19, 2020

doi:10.5430/afr.v9n3p53

URL: https://doi.org/10.5430/afr.v9n3p53

\begin{abstract}
This study aims to analyze the Effect of Dividend Policy, Economic Value Added (EVA), Market $\beta$ and Firm Size on Stock Return and the existence of Firm Size in moderating these effects of blue-chip stock category listed in Indonesia Stock Exchange (IDX) during 2015 up to 2019 period. This study is a confirmatory research involving secondary data collected from annual report available at IDX website. The sample used is purposive sampling and research object is Dividend Policy, EVA, Market $\beta$ and Firm Size as independent variables and Stock Return as dependent variable, and Firm Size as moderates variable. The analysis is performed using E-views 11.0 version. The result shows that Dividend Policy has significant negative effects while EVA and Market $\beta$ has no effect on Stock Return. In addition, Firm Size moderates the relation between Dividend Policy and Stock Return, while having no moderating effect to the relation between EVA, Market $\beta$ and Stock Return. The findings of this research imply that, for high stock performance like blue-chip stock, Dividend Policy affects the Stock Return and Firm Size moderates this effect.
\end{abstract}

Keywords: dividend policy, EVA, market $\beta$, firm size, stock return

\section{Introduction}

\subsection{The Background}

Many parties have interest on stock return information, both existing and potential investor, as well as the management and the state. With stock return information, investor could estimate earning while potential investor is more informed on their investment decision and firm management. Stock return information also describes the macro economy movements, when there is a general increase in stock returns of most companies, reflecting the development of economy. In the management side, the knowledge on factors affecting stock return assists management decision making to ensure that the company create value for investors, hence, stock return performance.

Theoretically, stock return is affected by multiple factors. Harper (2019) asserted that there are three factors consisting of fundamental, technical and market sentiment. Fundamental is the basic factor from internal organization. Meanwhile, technical element is the mix of internal and external condition that influence of stock supply and demand. Lastly, market sentiment is related to psychological factor of market players, which tended to be unlogic, bias and subjective. Most studies on stock price ignore the market sentiment factors due to the complexity of measuring such element. Fundamental and technical factors that affected stock return consisted of many variables. Among those factors, there are four variables, which are Dividend Policy, EVA, Market $\beta$ and Firm Sizes, providing variation in result, hence, inconsistencies in multiple studies.

The effect of Dividend Policy on Stock Return varied, with one stream of studies obtained a positively significant result (Ali et al, 2015, Hasan et al, 2013) while the other stream located a negatively significant result (Ahmad, 2018). Even, the effect of Dividend Policy on Stock Return was only relevant in the short run while becoming irrelevant in the long run. In similar manner, Previous studies are divided on the effect of EVA to Stock Return, with one side draw a positively significant result (among others are Putu et al., 2016, Hasheni, 2016, Pedro et al, 2018, Kumar and Subramayan, 2016, and Sang and Ning, 2017), while an opposing outcome were derived from Ela (2018), Eman (2017), Rahmi (2017) and Rizka (2018) studies. On the relationship between market $\beta$ and Stock Return, the discrepancy of results was also highlighted, with Mpofu (2011) and Xiao (2016) concluded that market $\beta$ significant positive affect on Stock Return while Rahmi (2017) stated otherwise. Meanwhile, the effect of Firm Size on Stock 
Return also come in variation, with Than Duy and Phuoc (2016) and Kijoyo (2009) found out a positive relationship while Abdullahi et al. (2011) found a negative relationship.

The variation in result on the effect of Dividend Policy, EVA, Market $\beta$ and Firm Size to Stock Return and the importance of stock return to company, capital market, and macroeconomy stand as the basis of the significance of the study.

\subsection{Literature Review and Hypotheses Development}

\subsubsection{Agency Theory and Signalling Theory}

The Agency Theory explains a condition, where third party (agent) appointed by the shareholder (principal) on behalf of shareholder, is bearing responsibility to ensure wealth creation for shareholders from time to time (Brigham et al, 2014). The agent is the management (Berk et all, 2011) who execute action to attain that mission, with Stock Retuyrn Level as a key performance indicator for management.

The Signalling Theory, which are coined by Akerlof (1970) and later developed by Spence (1973) dan Stiglitz ( (1985), is based on the presence of information asymmetry between parties (the individual and the organization, as well as the investor and the management) where a certain party take action to give a signal about a certain situation to mitigate asymmetry condition due to the problems of social selections under condition of imperfect information (Connelly et al, 2011)). In the corporation, the management is a party that is more informed about the firm operation, hence, the outside party level of information, especially shareholder, is determined by information provided by management. The signaling theory explains how management doing a series of action to give a certain information that needed by the shareholder.

\subsubsection{Stock Return}

Stock Return is the motivating force in the investment process. It is the reward for undertaking the investment (Bodie, Kane, Markus, 2010, Kasmir, 2016) which usually consisting of two components, which are (1) yield that measure cash flow in percentage related stock price like purchase price and market price, and (2) capital gain, which is the difference purchase and sales price or price change during transaction. This is because Stock Return is the sum of total yield and capital gain (Ross et al 2003). By ignoring the dividend, Stock Return could be measured by the percentage of the difference of the stock price of a certain and previous year, described in the following formula:

$$
\mathrm{SR}=(\mathrm{P} 1-\mathrm{P} 0) / \mathrm{P} 0 \text {, }
$$

where SR = Stock Return, P1 = Stock Price year now, P0 = last year stock price

\subsubsection{Dividend Policy}

The Dividend Policy is a policy related decision for the company to pay dividend to shareholder. If the company decided to pay, it is a policy related to value of the payment, its frequency, and all related policy for dividend decisions. The investor is waited for the information about Dividend policy, providing signal of either 'good' or 'bad' year. by nature, firm's dividend policy will affect stock return either in positive or negative manner. One form of dividend policy is related with the amount that firm pay measured as the proportion of dividend pay divided by profit after tax. The previous researches related the effect of Dividend Policy on Stock Return found on Sharif et al. (2015) and Hasan et al. (2013) which resulted positive significant relationship, while Ahmad (2018) stated negative significant affected with Irandoost et al. (2013) suggest that the positive significant effect is only short term in nature.

\section{H.1.: Dividend Policy affects Stock Return}

\subsubsection{Economic Value Added (EVA)}

EVA is a firm financial performance based on the residual wealth calculated by reducing the cost of capital from net profit after tax, which is usually termed as economic profit (Investopedia,2019, Bodie et al, 2011). The EVA formula is Net Operating Profit after Tax - (Invested Capital x WACC), where WACC is weighted average cost of capital (Bishop, 2013). As seen from the equation, it can be concluded that there is positive relation between the EVA and Stock Return. The studies related the effect of EVA on Stock Return found on Putu et al. (2016), Hasheni (2016), Pedro dkk (2018), and Kumar and Subramayan (2016), which resulted in positive significant effect.

H.2.: the EVA affects Stock Return

\subsubsection{Market $\beta$}

Market $\beta$ is a measurement of the systematic risk volatility of individual stock from the whole market risk. This shows the reaction change of individual stock from market change. The $\beta$ coefficient calculated with CAPM formula, which is 
shown in the equation below:

$\beta$ coefficient $=$ Covariance $($ Re- $\mathrm{Rm}) /$ Variance,

where $\mathrm{Re}=$ individual stock return, $\mathrm{Rm}=$ market stock return and the Covariance $=$ stock change proportion to market, the Variance $=$ the average of market data variation.

Since Market $\beta$ is related with individual stock reaction on market change, Market $\beta$ has positive correlation with Stock Return theoretically. Researches by Mpofu (2011) and Xiao (2016) concluded that market $\beta$ significant positive affect on Stock Return

\section{H.3.: Market $(\beta)$ affects Stock Return}

\subsubsection{Firm Size}

Firm Size is a firm measurement related firm scale (Trigueiros, 2000), where could be seen in sales volume, total asset value or market capitalization (Dang ad Li, 2013). The big company has relative opportunity to record high profit than the small one. The bigger the size of the company means the better opportunity in increasing firm profitability. Thus, there is positive relation between Firm Size and Stock Return. This study used Total Asset as measurement of Firm Size. Meanwhile positive significant result found related the effect of Firm Size on Stock Return on study by Than Duy \& Phuoc (2016), Kijoyo (2009),

\section{H.4.: Firm Size affects Stock Return}

There are also various researches investigated Firm Size, which assumed Firm Size as something that 'fixed' on firm performance (Kuncova et al, 2016) and is treated as control or moderating variable.

H.5.: Firm Size moderates the effect of Dividend Policy on Stock Return

H.6.: Firm Size moderates the effect of Economic Value Added on Stock Return

H.7.: Firm Size moderates the effect of Market $\beta$ on Stock Return

\subsubsection{Conceptual Framework and Hypotheses}

Based on theoretical perspective concluded that Dividend Policy, EVA, Market $\beta$ and Firm Size affects Stock Return as seen in Conceptual Framework, Figure 1,



\section{Research Methodology}

\subsection{Research Design, Population and Sample}

This study is designed as a confirmatory research with the purpose to verify the hypotheses concerning the effect of independent variables (Dividend Policy, Economic Value Added, Market $\beta$, Firm Size) on dependent variable (Stock Return) and whether Firm size moderates these effects. The population are blue-chip categorized companies with the best criteria which are (a) big market capitalization, (b) long listed in Indonesia Stock Exchange (IDX), (c) has positive financial performance, (d) becomes stock market leader and (e) has high liquidity during year 2015 up to 2019 data collected from web site IDX. The total amount of companies that consistent become blue-chip company member during observation is 15 companies.

\subsection{Variable Operationalization Definition}

The following table 2.1 is the summary of variable operationalization definition 
Table 1. The measurement and Variables Summary

\begin{tabular}{|c|c|c|c|}
\hline VARIABLE & DESCRIPTION & MEASUREMENT & SCALE \\
\hline $\begin{array}{l}\text { Dependent }(Y) \\
\text { Stock Return }\end{array}$ & $\begin{array}{l}\text { Firm's ability in obtaining } \\
\text { return for shareholder }\end{array}$ & $\begin{array}{l}\text { stock closing price year } \mathrm{t} \text { - stock } \\
\text { closing price year } \mathrm{t}-1 / \mathrm{stock} \text { closing } \\
\text { price year } \mathrm{t}-1\end{array}$ & Ratio \\
\hline $\begin{array}{l}\text { Independent }(\mathrm{x} 1) \\
\text { Dividend Policy }\end{array}$ & $\begin{array}{c}\text { The portion of Dividend } \\
\text { Paid Policy }\end{array}$ & $\frac{\text { Dividend Paid }}{\text { Net Profit after Tax }}$ & Ratio \\
\hline $\begin{array}{l}\text { Independent }\left(\mathrm{X}_{2}\right) \\
\text { Economic Value Added }\end{array}$ & $\begin{array}{l}\text { Firm's ability in obtaining } \\
\text { residual wealth for } \\
\text { shareholder }\end{array}$ & $\begin{array}{c}\text { Net Operating Profit After Tax- (Cap } \\
\text { Invested X WACC) }\end{array}$ & Ratio \\
\hline $\begin{array}{l}\text { Independent }\left(\mathrm{X}_{3}\right) \text { Market } \\
\beta\end{array}$ & $\begin{array}{l}\text { individual stock response } \\
\text { on market change }\end{array}$ & $\begin{array}{l}\beta=\frac{\mathrm{Rs}-\mathrm{Rf}}{\mathrm{Rm}-\mathrm{Rf}}, \\
\text { Rs= Return on Security, Rf= Risk Free } \\
\text { Rate Return, } \mathrm{Rm}=\text { Market Return }\end{array}$ & Ratio \\
\hline $\begin{array}{l}\text { Independent }\left(\mathrm{X}_{4}\right) \\
\text { Firm Size }\end{array}$ & The size of the firm & Ln of Total Asset & Ratio \\
\hline
\end{tabular}

Source: processed data,2020

\subsection{Method of Analysis}

Because the research involves panel data, the analysis uses Regression with E-views program 11 version through the following stages: a) Descriptive Statistical Analysis, b) Panel Data Regression Model Estimation, c) Selection of Regression model Estimation, d) Classical Assumption Test and e) Hypotheses Test.

\section{Result}

\subsection{Descriptive Statistical Analysis}

Table 2.2. Descriptive Statistic Test Result describes the data description that is seen from the average (mean), maximum, minimum and standard deviation of each variable.

Table 2. Descriptive Statistic Test Result

\begin{tabular}{lccccc}
\hline & STOCKR & DEVPOL & EVA & MB & FIRMSIZE \\
\hline Mean & -0.563822 & 0.544419 & 8472827. & 1.164070 & 8.242130 \\
Median & 0.023055 & 0.430185 & 4377607. & 1.194394 & 7.984697 \\
Maximum & 1.762431 & 2.014424 & $1.33 \mathrm{E}+09$ & 2.328432 & 10.91603 \\
Minimum & -35.33552 & 0.120823 & $-1.52 \mathrm{E}+09$ & -0.166360 & 7.196727 \\
Std. Dev. & 4.150281 & 0.346846 & $2.43 \mathrm{E}+08$ & 0.432559 & 0.865741 \\
Skewness & -8.014200 & 1.674579 & -1.078935 & -0.263010 & 1.217400 \\
Kurtosis & 67.50466 & 6.846497 & 34.07331 & 3.414555 & 4.572474 \\
& & & & & \\
Jarque-Bera & 13805.50 & 81.28874 & 3031.896 & 1.401731 & 26.25290 \\
Probability & 0.000000 & 0.000000 & 0.000000 & 0.496156 & 0.000002 \\
& & & & & \\
Sum & -42.28665 & 40.83140 & $6.35 \mathrm{E}+08$ & 87.30522 & 618.1598 \\
Sum Sq. Dev. & 1274.638 & 8.902364 & $4.37 \mathrm{E}+18$ & 13.84592 & 55.46349 \\
Observations & 75 & 75 & 75 & 75 & 75 \\
\hline
\end{tabular}

Source: E-views version 11, output, 2020 
Number of samples (N). The number of blue-chip categorized companies which are consistent for 5 years observations is 15 companies. The amount of data observed is 75 .

The Stock Return minimum value of -35.33552 , owned by PT. H.M. Sampoerna in 2015 and a maximum value of 1.762431 owned by PT Tambang Bukit Asam (Tbk) in 2016 with an average value of -0563822 and a variation of the average (standard deviation) of 4.150281 . With a mean of -0.563822 shows that on average for the last 5 years stock return of 15 companies is not good.

Dividend Policy has a minimum value of 0.120823 which is owned by PT. Astra Argo Lestari (Tbk) in 2016 and a maximum value of 2.014424 owned also by PT. Astra Argo Lestari (Tbk) in 2019. With an average value of 0.544419 and a variation of the average (standard deviation) of 0,346846 . With a mean of 0.544419 , it shows that the portion of Dividend paid more than $50 \%$ of firm's profit, is a good for business.

Economic Value Added has a Minimum value of - 1.52E+08 found at PT. Jasa Marga (Tbk) in 2015 and a maximum value of 0.1.33E+09 also owned by PT Jasa Marga (Tbk) in 2017. With an average value (mean) of 8472827 and a variation of the average (standard deviation) of $2.43 \mathrm{E}+08$ With a mean of 8472827 shows that positive Economic Value Added is a good sign for shareholder.

Market $\beta$ has a Minimum value of -0.166360 found at PT. Astra Argo Lestari (Tbk) in 2017 and a maximum value of 2.328432 is found in PT Gudang Garam (Tbk) in 2017. Hence, an average value of 1.164070 and a variation of the average (standard deviation) of 0.432559 . With a mean of 1.164070 shows that market change is responded more by blue-chip categorized companies.

Firm Size has minimum value of 7.196727, found at PT. Unilever (Tbk) in 2015 and a maximum value of 10.91603 is found in PT Gudang Garam (Tbk) in 2018. With an average value of 8.242130 and a variation of the average (standard deviation) of 0,865741 shows the range of Firm Size is narrow concluded the size of the firm categorized blue-chip on average.

\subsection{Panel Data Regression Model Estimation}

In analysis of the panel data regression model estimation there are 3 approaches of the regression model which is the Common Effect, Fixed Effect and Random Effect approaches. The results of each approach appear on table 2.3, 2.4 and 2.5.

Table 3. Common Effect Model

\begin{tabular}{|c|c|c|c|c|}
\hline \multicolumn{5}{|c|}{ Dependent Variable: STOCKR } \\
\hline \multicolumn{5}{|c|}{ Method: Panel Least Squares } \\
\hline \multicolumn{5}{|c|}{ Date: $08 / 10 / 20 \quad$ Time: $13: 23$} \\
\hline \multicolumn{5}{|l|}{ Sample: 20152019} \\
\hline \multicolumn{5}{|l|}{ Periods included: 5} \\
\hline \multicolumn{5}{|c|}{ Cross-sections included: 15} \\
\hline \multicolumn{5}{|c|}{ Total panel (balanced) observations: 75} \\
\hline Variable & Coefficient & Std. Error & t-Statistic & Prob. \\
\hline $\mathrm{C}$ & 8.752136 & 19.19344 & 0.455996 & 0.6499 \\
\hline DEVPOL & -13.37127 & 17.40963 & -0.768039 & 0.4452 \\
\hline EVA & $-1.40 \mathrm{E}-08$ & $1.80 \mathrm{E}-07$ & -0.077721 & 0.9383 \\
\hline MB & -3.259712 & 16.16154 & -0.201696 & 0.8408 \\
\hline FIRMSIZE & -0.873773 & 2.450654 & -0.356547 & 0.7226 \\
\hline DEVPOL*FIRMSIZE & 1.321324 & 2.205697 & 0.599050 & 0.5512 \\
\hline EVA*FIRMSIZE & $1.35 \mathrm{E}-09$ & $1.66 \mathrm{E}-08$ & 0.080977 & 0.9357 \\
\hline MB*FIRMSIZE & 0.325273 & 2.014285 & 0.161483 & 0.8722 \\
\hline
\end{tabular}




$\begin{array}{llll}\text { Root MSE } & 3.973907 & \text { R-squared } & 0.070798 \\ \text { Mean dependent var } & -0.563822 & \text { Adjusted R-squared } & -0.026282 \\ \text { S.D. dependent var } & 4.150281 & \text { S.E. of regression } & 4.204467 \\ \text { Akaike info criterion } & 5.810710 & \text { Sum squared resid } & 1184.395 \\ \text { Schwarz criterion } & 6.057909 & \text { Log likelihood } & -209.9016 \\ \text { Hannan-Quinn criter. } & 5.909414 & \text { F-statistic } & 0.729272 \\ \text { Durbin-Watson stat } & 1.274428 & \text { Prob(F-statistic) } & 0.647731\end{array}$

Source: E-views version 11, output, 2020

Table 4. Fixed Effect Model

\begin{tabular}{|c|c|c|c|c|}
\hline \multicolumn{5}{|c|}{ Dependent Variable: STOCKR } \\
\hline \multicolumn{5}{|c|}{ Method: Panel Least Squares } \\
\hline \multicolumn{5}{|c|}{ Date: $08 / 10 / 20 \quad$ Time: 13:33 } \\
\hline \multicolumn{5}{|l|}{ Sample: 20152019} \\
\hline \multicolumn{5}{|l|}{ Periods included: 5} \\
\hline \multicolumn{5}{|c|}{ Cross-sections included: 15} \\
\hline \multicolumn{5}{|c|}{ Total panel (balanced) observations: 75} \\
\hline Variable & Coefficient & Std. Error & t-Statistic & Prob. \\
\hline $\mathrm{C}$ & 15.77925 & 29.54426 & 0.534088 & 0.5955 \\
\hline DEVPOL & -45.53687 & 44.45493 & -1.024338 & 0.3103 \\
\hline EVA & 5.07E-07 & 5.39E-07 & 0.939805 & 0.3516 \\
\hline MB & -7.335377 & 25.78033 & -0.284534 & 0.7771 \\
\hline FIRMSIZE & -2.113496 & 3.848733 & -0.549141 & 0.5852 \\
\hline DEVPOL*FIRMSIZE & 5.847171 & 5.893095 & 0.992207 & 0.3256 \\
\hline EVA*FIRMSIZE & $-4.65 \mathrm{E}-08$ & 4.96E-08 & -0.938502 & 0.3522 \\
\hline MB*FIRMSIZE & 0.857759 & 3.263730 & 0.262816 & 0.7937 \\
\hline
\end{tabular}

Effects Specification

Cross-section fixed (dummy variables)

$\begin{array}{llll}\text { Root MSE } & 3.619035 & \text { R-squared } & 0.229345 \\ \text { Mean dependent var } & -0.563822 & \text { Adjusted R-squared } & -0.076009 \\ \text { S.D. dependent var } & 4.150281 & \text { S.E. of regression } & 4.305122 \\ \text { Akaike info criterion } & 5.996959 & \text { Sum squared resid } & 982.3061 \\ \text { Schwarz criterion } & 6.676755 & \text { Log likelihood } & -202.8859 \\ \text { Hannan-Quinn criter. } & 6.268394 & \text { F-statistic } & 0.751079 \\ \text { Durbin-Watson stat } & 1.541023 & \text { Prob(F-statistic) } & 0.761047\end{array}$

Source: E-views version 11, output, 2020 
Table 5. Random Effect Model

\begin{tabular}{|c|c|c|c|c|}
\hline \multicolumn{5}{|c|}{ Dependent Variable: STOCKR } \\
\hline \multicolumn{5}{|c|}{ Method: Panel EGLS (Cross-section random effects) } \\
\hline \multicolumn{5}{|c|}{ Date: $08 / 10 / 20 \quad$ Time: $13: 37$} \\
\hline \multicolumn{5}{|l|}{ Sample: 20152019} \\
\hline \multicolumn{5}{|l|}{ Periods included: 5} \\
\hline \multicolumn{5}{|c|}{ Cross-sections included: 15} \\
\hline \multicolumn{5}{|c|}{ Total panel (balanced) observations: 75} \\
\hline \multicolumn{5}{|c|}{ Swamy and Arora estimator of component variances } \\
\hline Variable & Coefficient & Std. Error & t-Statistic & Prob. \\
\hline $\mathrm{C}$ & 8.602558 & 19.99153 & 0.430310 & 0.6684 \\
\hline DEVPOL & -13.28363 & 18.29444 & -0.726102 & 0.4703 \\
\hline EVA & $-9.51 \mathrm{E}-09$ & 1.92E-07 & -0.049594 & 0.9606 \\
\hline MB & -3.362874 & 16.94314 & -0.198480 & 0.8433 \\
\hline FIRMSIZE & -0.866016 & 2.554949 & -0.338956 & 0.7357 \\
\hline DEVPOL*FIRMSIZE & 1.321777 & 2.320604 & 0.569583 & 0.5709 \\
\hline EVA*FIRMSIZE & $9.32 \mathrm{E}-10$ & $1.77 \mathrm{E}-08$ & 0.052685 & 0.9581 \\
\hline MB*FIRMSIZE & 0.341027 & 2.113172 & 0.161381 & 0.8723 \\
\hline
\end{tabular}

Effects Specification

$\begin{array}{lll}\text { Cross-section random } & 0.601789 & 0.0192 \\ \text { Idiosyncratic random } & 4.305122 & 0.9808\end{array}$

Weighted Statistics

$\begin{array}{llll}\text { Root MSE } & 3.947624 & \text { R-squared } & 0.066452 \\ \text { Mean dependent var } & -0.538146 & \text { Adjusted R-squared } & -0.031083 \\ \text { S.D. dependent var } & 4.113222 & \text { S.E. of regression } & 4.176659 \\ \text { Sum squared resid } & 1168.780 & \text { F-statistic } & 0.681311 \\ \text { Durbin-Watson stat } & 1.289936 & \text { Prob(F-statistic) } & 0.687259\end{array}$

Unweighted Statistics

Source: E-views version 11, output, 2020

\begin{tabular}{llll} 
R-squared & 0.070744 & Mean dependent var & -0.563822 \\
Sum squared resid & 1184.465 & Durbin-Watson stat & 1.272854 \\
\hline
\end{tabular}

\subsection{Selection of Panel Data Regression Model Estimation}

There are three approaches to select panel data regression model estimation to find the best regression model, namely Chow test, Hausman test and Lagrange Multiplier Test.

3.3.1 Chow Test

Chow test compares Common Effect and Fixed Effect model with hypotheses as follows: 
H0: Model Common Effect

H1: Model Fixed Effect

$\mathrm{H} 0$ is rejected if the P-value is smaller than $\alpha(5 \%)$. Conversely, $\mathrm{H} 0$ is accepted if the P-value is greater than the value of $\alpha$. By using E-views 11 version, the result of data processing is as follows:

Table 6. Chow Test Result

\begin{tabular}{llll}
\hline Redundant Fixed Effects Tests & & & \\
$\begin{array}{l}\text { Equation: Untitled } \\
\text { Test cross-section fixed effects }\end{array}$ & & & \\
Effects Test & Statistic & d.f. & Prob. \\
& & & \\
Cross-section F & 0.778833 & $(14,53)$ & 0.6864 \\
Cross-section Chi-square & 14.031355 & 14 & 0.4474
\end{tabular}

Cross-section fixed effects test equation:

Dependent Variable: STOCKR

Method: Panel Least Squares

Date: 08/10/20 Time: 13:50

Sample: 20152019

Periods included: 5

Cross-sections included: 15

Total panel (balanced) observations: 75

$\begin{array}{lllll}\text { Variable } & \text { Coefficient } & \text { Std. Error } & \text { t-Statistic } & \text { Prob. } \\ \text { C } & 8.752136 & 19.19344 & 0.455996 & 0.6499 \\ \text { DEVPOL } & -13.37127 & 17.40963 & -0.768039 & 0.4452 \\ \text { EVA } & -1.40 \mathrm{E}-08 & 1.80 \mathrm{E}-07 & -0.077721 & 0.9383 \\ \text { MB } & -3.259712 & 16.16154 & -0.201696 & 0.8408 \\ \text { FIRMSIZE } & -0.873773 & 2.450654 & -0.356547 & 0.7226 \\ \text { DEVPOL*FIRMSIZE } & 1.321324 & 2.205697 & 0.599050 & 0.5512 \\ \text { EVA*FIRMSIZE } & 1.35 \mathrm{E}-09 & 1.66 \mathrm{E}-08 & 0.080977 & 0.9357 \\ \text { MB*FIRMSIZE } & 0.325273 & 2.014285 & 0.161483 & 0.8722 \\ & & & \\ \text { Root MSE } & 3.973907 & \text { R-squared } & 0.070798 \\ \text { Mean dependent var } & -0.563822 & \text { Adjusted R-squared } & -0.026282 \\ \text { S.D. dependent var } & 4.150281 & \text { S.E. of regression } & 4.204467 \\ \text { Akaike info criterion } & 5.810710 & \text { Sum squared resid } & 1184.395 \\ \text { Schwarz criterion } & 6.057909 & \text { Log likelihood } & -209.9016 \\ \text { Hannan-Quinn criter. } & 5.909414 & \text { F-statistic } & 0.729272 \\ \text { Durbin-Watson stat } & 1.274428 & \text { Prob(F-statistic) } & 0.647731\end{array}$

Source: E-views version 11, output, 2020

With a significance level of $5 \%(\alpha=0.05)$, the result of Chow test showed that the p-value F Test of $0.6864>\alpha(0.05)$, therefore Ho (Common Effect Model) is accepted

\subsubsection{Hausman Test}

The Hausman Test as a statistical test is to pick between Fixed Effect and random-effects models, which are the most preferable. The Hausman test is performed with the following hypothesis: 
H0: Random Effect Model

H1: Fixed Effect Model

If the P-value $<0.05$ then $\mathrm{H} 0$ is rejected, the method chosen is a fixed effect. If $\mathrm{p}$ value $>0.05$ then the method selected is a random effect. The result of these tests shown in the table 2.7:

Table 7. Hausman Test Result

\begin{tabular}{llll}
\hline Correlated Random Effects - Hausman Test & & \\
\hline Equation: Untitled & & & \\
Test cross-section random effects & & & \\
& $\begin{array}{l}\text { Chi-Sq. } \\
\text { Statistic }\end{array}$ & Chi-Sq. d.f. & Prob. \\
Test Summary & 3.061151 & 7 & 0.8793
\end{tabular}

Cross-section random effects test comparisons:

$\begin{array}{lllll}\text { Variable } & \text { Fixed } & \text { Random } & \text { Var(Diff.) } & \text { Prob. } \\ \text { DEVPOL } & -45.536874 & -13.283628 & 1641.554780 & 0.4260 \\ \text { EVA } & 0.000001 & -0.000000 & 0.000000 & 0.3057 \\ \text { MB } & -7.335377 & -3.362874 & 377.555560 & 0.8380 \\ \text { FIRMSIZE } & -2.113496 & -0.866016 & 8.284979 & 0.6647 \\ \text { DEVPOL*FIRMSIZE } & 5.847171 & 1.321777 & 29.343366 & 0.4035 \\ \text { EVA*FIRMSIZE } & -0.000000 & 0.000000 & 0.000000 & 0.3055 \\ \text { MB*FIRMSIZE } & 0.857759 & 0.341027 & 6.186437 & 0.8354\end{array}$

Cross-section random effects test equation:

Dependent Variable: STOCKR

Method: Panel Least Squares

Date: 08/10/20 Time: 14:10

Sample: 20152019

Periods included: 5

Cross-sections included: 15

Total panel (balanced) observations: 75

$\begin{array}{lcccc}\text { Variable } & \text { Coefficient } & \text { Std. Error } & \text { t-Statistic } & \text { Prob. } \\ \text { C } & 15.77925 & 29.54426 & 0.534088 & 0.5955 \\ \text { DEVPOL } & -45.53687 & 44.45493 & -1.024338 & 0.3103 \\ \text { EVA } & 5.07 \mathrm{E}-07 & 5.39 \mathrm{E}-07 & 0.939805 & 0.3516 \\ \text { MB } & -7.335377 & 25.78033 & -0.284534 & 0.7771 \\ \text { FIRMSIZE } & -2.113496 & 3.848733 & -0.549141 & 0.5852\end{array}$




$\begin{array}{lllll}\text { DEVPOL*FIRMSIZE } & 5.847171 & 5.893095 & 0.992207 & 0.3256 \\ \text { EVA*FIRMSIZE } & -4.65 \mathrm{E}-08 & 4.96 \mathrm{E}-08 & -0.938502 & 0.3522 \\ \text { MB*FIRMSIZE } & 0.857759 & 3.263730 & 0.262816 & 0.7937\end{array}$

Effects Specification

Cross-section fixed (dummy variables)

$\begin{array}{llll}\text { Root MSE } & 3.619035 & \text { R-squared } & 0.229345 \\ \text { Mean dependent var } & -0.563822 & \text { Adjusted R-squared } & -0.076009 \\ \text { S.D. dependent var } & 4.150281 & \text { S.E. of regression } & 4.305122 \\ \text { Akaike info criterion } & 5.996959 & \text { Sum squared resid } & 982.3061 \\ \text { Schwarz criterion } & 6.676755 & \text { Log likelihood } & -202.8859 \\ \text { Hannan-Quinn criter. } & 6.268394 & \text { F-statistic } & 0.751079 \\ \text { Durbin-Watson stat } & 1.541023 & \text { Prob(F-statistic) } & 0.761047\end{array}$

Source: E-views version 11, output, 2020

Based on table 2.7, it showed a random cross-section p-value of $0.8793>0.05$ with a significance level of $5 \%$. Thus, it stated that the Random Effect Model is the selected model.

3.3.3 Lagrange Multiplier Test

It is executed to find the best model between the common effect or random effect. The hypothesis used is:

H0: Common Effect Model

H1: Random Effect Model

With the clauses: $\mathrm{H} 0$ is rejected if the value of Prob. Breusch-Pagan (BP-value) is smaller than the value of $\alpha(5 \%)$ and $\mathrm{H} 0$ is accepted if the value is Prob. Breusch-Pagan (BP-value) is greater than the $\alpha$ value.

Table .8 Lagrange Multiplier Test Result

\begin{tabular}{|c|c|c|c|}
\hline \multicolumn{4}{|c|}{ Lagrange Multiplier Tests for Random Effects } \\
\hline \multicolumn{4}{|c|}{ Null hypotheses: No effects } \\
\hline \multicolumn{4}{|c|}{$\begin{array}{l}\text { Alternative hypotheses: Two- } \\
\text { (all others) alternatives }\end{array}$} \\
\hline & \multicolumn{3}{|c|}{ Test Hypothesis } \\
\hline & Cross-section & Time & Both \\
\hline \multirow[t]{2}{*}{ Breusch-Pagan } & 0.646044 & 0.683036 & 1.329080 \\
\hline & $(0.4215)$ & $(0.4085)$ & $(0.2490)$ \\
\hline \multirow[t]{2}{*}{ Honda } & -0.803769 & 0.826460 & 0.016045 \\
\hline & $(0.7892)$ & $(0.2043)$ & $(0.4936)$ \\
\hline \multirow[t]{2}{*}{ King-Wu } & -0.803769 & 0.826460 & 0.349969 \\
\hline & $(0.7892)$ & $(0.2043)$ & $(0.3632)$ \\
\hline
\end{tabular}




$\begin{array}{llll}\text { Standardized Honda } & -0.220026 & 1.199458 & -3.093713 \\ & (0.5871) & (0.1152) & (0.9990) \\ \text { Standardized King-Wu } & -0.220026 & 1.199458 & -2.284532 \\ & (0.5871) & (0.1152) & (0.9888) \\ \text { Gourieroux, et al.* } & -- & -- & 0.683036 \\ & & & (0.3819)\end{array}$

Source: E-Views, version 11, output, 2020

Table 2.8. showed that the value of Prob. Breusch-Pagan (BP-value) of $0.4215>\alpha(0.05)$ thus, H0 (Common Effect Model) accepted, meaning that the selected model is Common Effect Model.

The summary of Chow, Hausman and Lagrange Multiplier test presented in table 9 below concluded that the model selected is Common Effect Model as presented on table 2.3.

Table 9. The Summary Test Result

\begin{tabular}{lllll}
\hline Test Type/Model & Common Effect & Fixed Effect & Random Effect & Result \\
\hline Chow & $\mathrm{V}$ & $\mathrm{V}$ & & Common Effect \\
Hausman & & $\mathrm{V}$ & $\mathrm{V}$ & Random Effect \\
Lagrange Multiplier & $\mathrm{V}$ & & $\mathrm{V}$ & Common Effect \\
\hline
\end{tabular}

Source: Data Processed,2020

\subsection{Classical Assumption Test}

Classical assumption test in panel data regression analysis is done to ensure that the panel data analysis is free from violation and biasness of assumption, which caused misinterpretation on panel data regression analysis. There are three primary problems often appears that affects unfulfilled basic assumption known as BLUE (Best Linear Unbiased Estimator) that is Multicollinearity, Heteroscedasticity and Autocorrelation.

\subsubsection{Multicollinearity Test}

Multicollinearity is a perfect linear correlation between independent variables in regression model. To measure the occurrence of multicollinearity could be seen from coefficient correlation between independent variables, if the coefficient $>0.80$ states that multicollinearity occurred, vice versa. As shown on table 2.10 below, there is no coefficient that $>0.80$, concluded that multicollinearity does not occur.

Table 10. The Multicollinearity Test Result

\begin{tabular}{lrlll}
\hline & DEVPOL & EVA & MB & FIRMSIZE \\
\hline DEVPOL & 1.000000 & -0.354421 & -0.018565 & -0.304926 \\
EVA & -0.354421 & 1.000000 & -0.150567 & 0.069380 \\
MB & -0.018565 & -0.150567 & 1.000000 & 0.289051 \\
$\begin{array}{lrlll}\text { FIRMSIZ } \\
\text { E }\end{array}$ & -0.304926 & 0.069380 & 0.289051 & 1.000000 \\
\hline
\end{tabular}

Source: Data Processed,2020

\subsubsection{Heteroscedasticity Test}

Based on table 2.9, it is concluded that the selected regression model is Common Effect Model as presented on table 2.3 , one of the ways to test the occurrence of heteroscedasticity occurrence is by giving the weight on Common Effect Model then comparing this model in unweighted and weighted. Unweighted Common Effect Model has been already presented on table 2.3 and restated on table 2.11 while the weighted model shown on table 2.12 as following: 
Table 11. Unweighted Common Effect Model

\begin{tabular}{|c|c|c|c|c|}
\hline \multicolumn{5}{|c|}{ Dependent Variable: STOCKR } \\
\hline \multicolumn{5}{|c|}{ Method: Panel Least Squares } \\
\hline Date: $08 / 10 / 20 \quad$ Time & \multicolumn{4}{|c|}{ Time: $13: 23$} \\
\hline \multicolumn{5}{|l|}{ Sample: 20152019} \\
\hline \multicolumn{5}{|l|}{ Periods included: 5} \\
\hline \multicolumn{5}{|c|}{ Cross-sections included: 15} \\
\hline \multicolumn{5}{|c|}{ Total panel (balanced) observations: 75} \\
\hline Variable & Coefficient & Std. Error & t-Statistic & Prob. \\
\hline $\mathrm{C}$ & 8.752136 & 19.19344 & 0.455996 & 0.6499 \\
\hline DEVPOL & -13.37127 & 17.40963 & -0.768039 & 0.4452 \\
\hline EVA & $-1.40 \mathrm{E}-08$ & $1.80 \mathrm{E}-07$ & -0.077721 & 0.9383 \\
\hline MB & -3.259712 & 16.16154 & -0.201696 & 0.8408 \\
\hline FIRMSIZE & -0.873773 & 2.450654 & -0.356547 & 0.7226 \\
\hline DEVPOL*FIRMSIZE & 1.321324 & 2.205697 & 0.599050 & 0.5512 \\
\hline EVA*FIRMSIZE & $1.35 \mathrm{E}-09$ & $1.66 \mathrm{E}-08$ & 0.080977 & 0.9357 \\
\hline MB*FIRMSIZE & 0.325273 & 2.014285 & 0.161483 & 0.8722 \\
\hline Root MSE & 3.973907 & R-squar & & 0.070798 \\
\hline Mean dependent var & -0.563822 & Adjuste & -squared & -0.026282 \\
\hline S.D. dependent var & 4.150281 & S.E. of 1 & ession & 4.204467 \\
\hline Akaike info criterion & 5.810710 & Sum squ & d resid & 1184.395 \\
\hline Schwarz criterion & 6.057909 & Log like & od & -209.9016 \\
\hline Hannan-Quinn criter. & 5.909414 & F-statist & & 0.729272 \\
\hline Durbin-Watson stat & 1.274428 & $\operatorname{Prob}(\mathrm{F}-$ & istic) & 0.647731 \\
\hline
\end{tabular}

Source: E-views version 11, output, 2020

Table 12. Weighted Common Effect Model

Dependent Variable: STOCKR

Method: Panel EGLS (Cross-section weights)

Date: 08/10/20 Time: 20:53

Sample: 20152019

Periods included: 5

Cross-sections included: 15

Total panel (balanced) observations: 75

Linear estimation after one-step weighting matrix

Variable Coefficient Std. Error t-Statistic Prob.

\begin{tabular}{lllll} 
C & 4.295096 & 2.186097 & 1.964732 & 0.0536 \\
DEVPOL & -5.652186 & 2.234758 & -2.529216 & 0.0138 \\
\hline
\end{tabular}

$\begin{array}{lllll}\text { DEVPOL } & -5.652186 & 2.234758 & -2.529216 & 0.0138\end{array}$




\begin{tabular}{lllll}
\hline EVA & $1.03 \mathrm{E}-08$ & $1.89 \mathrm{E}-08$ & 0.547398 & 0.5859 \\
MB & -1.190735 & 2.197312 & -0.541906 & 0.5897 \\
FIRMSIZE & -0.469492 & 0.254649 & -1.843684 & 0.0697 \\
DEVPOL*FIRMSIZE & 0.644003 & 0.259442 & 2.482263 & 0.0156 \\
EVA*FIRMSIZE & $-8.99 \mathrm{E}-10$ & $1.73 \mathrm{E}-09$ & -0.519052 & 0.6054 \\
MB*FIRMSIZE & 0.127781 & 0.255738 & 0.499659 & 0.6190
\end{tabular}

Weighted Statistics

$\begin{array}{llll}\text { Root MSE } & 2.638538 & \text { R-squared } & 0.274072 \\ \text { Mean dependent var } & 0.155549 & \text { Adjusted R-squared } & 0.198228 \\ \text { S.D. dependent var } & 3.242916 & \text { S.E. of regression } & 2.791621 \\ \text { Sum squared resid } & 522.1410 & \text { F-statistic } & 3.613658 \\ \text { Durbin-Watson stat } & 1.746309 & \text { Prob(F-statistic) } & 0.002317\end{array}$

Unweighted Statistics

$\begin{array}{llll}\text { R-squared } & 0.004152 & \text { Mean dependent var } & -0.563822 \\ \text { Sum squared resid } & 1269.345 & \text { Durbin-Watson stat } & 1.191062\end{array}$

Source: E-views version 11, output, 2020

The comparation between unweighted and weighted Common Effect Model appears on table 2.13

Table 13. Comparation of Unweighted and Weighted Common Effect Model

\begin{tabular}{lll}
\hline Parameter & Unweighted Common Effect Model & Weighted Common Effect Model \\
\hline t Statistic Probability & No item $<0.05$ & 2 items $<0.05$ \\
R-Squared & 0.07 & 0.27 \\
F Statistic Probability & 0.647731 & 0.002317 \\
\hline
\end{tabular}

Source: E-views version 11, output, 2020

As depicted on table 2.13, from 3 parameters indicator, T Statistic probability, R-Squared and F-Statistic Probability concluded that the Weighted Common Effect Model is the better model than the Unweighted, therefore the final panel data regression model is Weighted Common Effect Model.

\subsubsection{Autocorrelation Test}

Autocorrelation is a condition where correlation between observation, whether in time series or cross-section observation existed. Usually, autocorrelation collided on time series characterized data. Moreover, there is no features when panel data used on e-views (Ghozali and Ratmono,2016)

\subsection{Hypotheses Test}

All following discussion on this part based on table 2.12.

\subsubsection{Formulation of Panel Data Regression Model}

Selection of Panel Data Regression Model Estimation resulted that Weighted Common Effect Model is a chosen model. Thus, panel data regression equation can be formed as follows:

Stockr $(Y)=4.295096-5.652186($ devpol $)+1.03 \mathrm{E} .08$ (eva) $-1.190735(\mathrm{mb})-0.469492$ (firm size)

\subsubsection{Coefficient Determination}

Based on Weighted Common Effect model, the adjusted R-Squared value is 0.198228. This means that the independent variables, dividend policy, economic value added, market $\beta$ and firm size can explain stock return of 19,82 
$\%$, while the remaining $80.18 \%$ is influenced by other variables outside the model. The R-Squared value obtained $27.40 \%$ indicates that the effect of all independent variables on stock return is not strong because the score $<50 \%$.

\subsubsection{The F- Test (simultaneous)}

The calculated F-value of 3.613658 with probability of $0.002317<0.05$ asserts that together all independent variables which consisted of dividend policy, economic value added, market $\beta$ and firm size affect Stock Return, so the model is feasible.

\subsubsection{The t Test (partial)}

It is concluded that only Dividend Policy Variable effect on Stock Return negatively caused the probability of $0.0138<$ 0.05 , while 3 other variables EVA (0.5859), Market $\beta(0.5897)$ and Firm Size $(0.0697)$ wherein each probability $>0.05$ means it has no effect on Stock Return. In the other side of moderating variables, it is only the relation between Dividend Policy and Firm Size that is significance at value of 0,0156<0,05. This means that Firm Size strengthen the relation between Dividend Policy and Stock Return in other word Firm Size moderates the effect of Dividend Policy on Stock Return, the other two, EVA-FIRM SIZE (0.6054 of significance value ) and Market $\beta$-Firm Size ( 0.6190 ) does not strengthen/weaken the Stock Return.

\subsubsection{Summary of Hypotheses Test Result}

The following table 2.14. portrays the hypotheses test result

Table 14. The Summary of Hypotheses Test Result

\begin{tabular}{|c|c|c|c|}
\hline $\mathrm{H}$ & Hypotheses & Result & Decision \\
\hline 1 & Dividend Policy affects Stock Return & $\begin{array}{l}\text { Dividend Policy Significant effect on Stock } \\
\text { Return }\end{array}$ & Accepted \\
\hline 2 & EVA affects Stock Return & EVA has no significant effect on Stock Return & Rejected \\
\hline 3 & Market $(\beta)$ affects Stock Return & $\begin{array}{l}\text { Market }(\beta) \text { has no significant effect on Stock } \\
\text { Return }\end{array}$ & Rejected \\
\hline 4 & Firm Size affects Stock Return & $\begin{array}{l}\text { Firm Size has no significant effect on Stock } \\
\text { Return }\end{array}$ & Rejected \\
\hline 5 & $\begin{array}{l}\text { Firm Size moderates the effect of } \\
\text { Dividend Policy on Stock Return }\end{array}$ & $\begin{array}{l}\text { Firm Size significant affect in moderating the } \\
\text { relation between Dividend Policy and Stock } \\
\text { Return }\end{array}$ & Accepted \\
\hline 6 & $\begin{array}{l}\text { Firm Size moderates the effect of } \\
\text { Economic Value Added on Stock } \\
\text { Return }\end{array}$ & $\begin{array}{l}\text { Firm Size has no significant effect in moderating } \\
\text { the relation between EVA and Stock Return }\end{array}$ & Rejected \\
\hline 7 & $\begin{array}{l}\text { Firm Size moderates the effect of } \\
\text { Market } \beta \text { on Stock Return }\end{array}$ & $\begin{array}{l}\text { Firm Size has no significant effect in moderating } \\
\text { the relation between Market } \beta \text { and Stock Return }\end{array}$ & Rejected \\
\hline
\end{tabular}

Source: Processed Data, 2020

\section{Discussion}

\subsection{The Effect of Dividend Policy on Stock Return}

The result of hypotheses test is that Dividend Policy affects negatively on Stock Return. This means that the greater the dividend paid by company eventually decreases the Stock Return. The possible reason is that the firm's Dividend Policy precepted as a bad news by the investor, resulting in the decrease of stock return. As statement of signaling theory, management action in the form of Dividend Policy is a signal from management to the investor. The investor reacts based on the nature the signal, good or bad news, reflected in the Stock Price, hence, the Stock Return. The Dividend Policy affects negatively on Stock Return of blue-chip stock during year 2015 up to 2019, which is in line the finding of Ahmad (2018). 


\subsection{The Effect of EVA on Stock Return}

The result above suggested that EVA does not significantly affect Stock Return. This means that, when EVA fluctuates, the Stock Return does not follow. It is in opposition to the concept in accounting that profit fluctuation must be followed by the fluctuation of Stock Return as it is not the case. This might be because of the existence of information asymmetry between management that announces the EVA and the investor that does not react accordingly to influence the Stock Price, hence, does not follow the EVA fluctuation. This finding is in line with studies by Ela (2018), Eman (2017), Rahmi (2017) and Rizka (2018).

\subsection{The Effect of Market $\beta$ on Stock Return}

Hypotheses test resulted that Market $\beta$ does not significantly affect Stock Return. This means that, as Market $\beta$ fluctuates, the Stock Return does not follow the movement. It is in line with finding of Rahmi (2017), yet, in opposition from the financial concept related the formula for Market $\beta$, which indicates that when Market $\beta$ fluctuates so does the Stock Return. Statistically, it is because of the value of deviation standard less than its average (mean), made the Stock Return does not follow when Market $\beta$ fluctuates. This is a condition persist among companies grouped as blue-chip stock during period year 2015 up to 2019. Thus, Market $\beta$ is not a factor that affect Stock Return.

\subsection{The Effect of Firm Size on Stock Return}

Hypotheses test find that Firm Size does not affect the Stock Return. This is in contrast with the pre-supposed concept that suggest that the larger the firm can be translated as larger opportunity to increase its financial profit to drive up the Stock Return (Than Duy \& Phuoc, 2016; Kijoyo,2009). The possible reason is that Firm Size is related with long-term investment, especially capital budgeting. The result of the fluctuation of Firm Size cannot be seen in the short-term. As a result, Firm Size affects Stock Return in negative way for companies grouped in blue-chip stock listed in IDX during year 2015 up 2019.

\subsection{Firm Size Moderates the effect of Dividend Policy on Stock Return}

Statistic test advise this research that Firm Size moderates the relation between Dividend Policy and Stock Return. This means that the larger the amount of dividend paid by the firm eventually affect the Stock Return positively.

\subsection{Firm Size Moderates the Effect of Economic Value Added on Stock Return}

Hypotheses test suggests that Firm Size does not moderate the relation between EVA and Stock Return. This means that Firm Size cannot strengthen or weaken the relation between EVA and Stock Return. In that manner, the EVA does not affect Stock Return.

\subsection{Firm Size Moderates the Effect of Market $\beta$ on Stock Return}

The resulted from model suggests that Firm Size does not moderate the relation between Market $\beta$ and Stock Return. This means that Firm Size cannot strengthen or weaken the relation between Market $\beta$ and Stock Return.

\section{Conclusion and Suggestion}

\subsection{Conclusion}

The effect of independent variables represented by Dividend Policy, Economic Value Added, and Market $\beta$ on Stock Return are not strong. Among all independent variables, Dividend Policy is the only individual factor that has a significant negative effect on Stock Return, while Economic Value Added, Market $\beta$ and Firm Size do not affect Stock Return. In moderating variable, Firm Size has significant positive effect in moderating the relation between Dividend Policy and Stock Return, while Firm Size has no significant effect in moderating the relation between Economic Value Added, Market $\beta$ and Stock Return. This study implies that in the preparation of performance improvement strategies in the form of Stock Return, firm management is advised to consider more in Dividend Policy because empirical result promote Dividend Policy as an element to be considered to ensure the Stock Return fluctuation.

\subsection{Suggestion}

Since the effect of Dividend Policy, Economic Value Added, Market $\beta$ on Stock Return are not strong, it is suggested to future researcher should consider exploring about Stock Return determinant in depth by adding other related variables, which resulted in higher R-square value as proxied of better model of Stock Return determinant. It also suggested that firm management should consider Dividend Policy and Firm Size in their performance improvement strategies in the form of Stock Return given the output of the study. 


\section{References}

Abdullahi, LB; WA, Lawal; Muhtar, Etudaiye. 2011. The Effect of Firms Size on Risk and Return in the Nigeria Stock Market: A Sectoral Analysis. British Journal of Economics, Finance and Management Science, 1.

Ahmad, Muhammad Akram; Salem Alrjoub, Ashraf Mohammad; Alrabba, Hussein Mohammad. 2018. The Effect of Dividen Policy on Stock Prices Volatility: Empirical Evidence from Amman Stock Exchange. Academy of Accounting and Financial Studies Journal, 22(2). https://doi.org/10.13140/RG.2.2.26262.09289

Al Hasan, Md. Abdullah; Asaduzzaman; Al Karim, Rashed. (2013). The Effect of Dividend Policy on Share Price: An Evaluation Study. IQSR Journal of Economics and Finance, 1(4). https://doi.org/10.9790/5933-0140611

Ali, Adnan; Ali Jan, Farzand; Sharif, Ilyas, 2015. Effect of Dividend Policy on Stock Prices. Business and Management Studies: An International Journal, 3(1). http://doi.org/10.15295/bmij.v3i1.101

Brigham, Eugene F; Houston, Joel F.(2014). Fundamental of Financial Management, University of Florida, Thomson Southwestern, USA.

Berk, Jonathan; DeMarzo, Peter.(2011).Corporate Finance, second edition,Stanford University, Pearson International, USA.

Bishop, Steven; Faff, Robert; Oliver, Barry; Twite, Garry, 2004. Corporate Finance, Pearson Prentice Hall Inc.

Connely, B; Certo, T; Ireland, D; Reutzel, C.2011. Signaling theory: A review and assessment. Journal Management, 37, 39-67. (Cross Ref). https://doi.org/10.1177/0149206310388419

Chen, James, 2019. Market Value Added, Corporate Finance and Accounting > Financial Analysis, Investopedia.

Fatin, Rachmi, 2017. "Pengaruh EVA, MVA, Kebijakan Dividen dan Beta Terhadap Return Saham Pada Perusahaan Manufaktur Yang Terdaftar Di BEI 2011-2015. Profita Kajian Ilmu Akuntansi, 5(8).

Ghozali, I \& Ratmono, D, 2013. Analisis Multivariat dan Ekonometrika: Teori, Konsep dan Aplikasi dengan E-views 8. Semarang: Badan Peneribit Universitas Diponegoro.

Harper, David R..2019. Forces that Move Stock Prices. Investopedia.

Irandoost, Roza; Hassanzadeh, Rasoul Baradaran; Salteh, Heydar Mohammadzadeh. 2013. The Effect of Dividen Policy on Stock Price Volatility and Investment Decision. European Online Journal of Natural and Social Sciencxes.

Kuncova, M; Hedija, V; Fiala,R, 2016. Firm Size as a determinant of Firm Performance: The Case of Swine Raising. Agris on-line Papers in Economics and Informatics, VIII(3). https://doi.org/10.7160/aol.2016.080308

Mpofu, Raphael T. 2011. The Relationship between Beta and Stock Returns in th4e JSE Securities Exchange in South Africa. Corporate Ownership and Control, 9(1). https://doi.org/10.22495/cocv9i1c5art5

Nainggolan, Rocky R. 2016. "Analisis Pengaruh Return on Assets (ROA), Economic Value Added (EVA), dan Market Value Added (MVA) Terhadap Return Saham”. Jurnal Riset Bisnis dan Manajemen, 4(2), 115-128.

Ngo Anton, Kijoyo, 2009. The Effect of Firm Size on Stock Returns Evidence from Indonesia Stock Exchange. Electronic Theses and Desertations (ETD) Gajah Mada University.

Rizka Ayu Kusuma dan Topowijono.2018. "Pengaruh Economic Value Added (EVA) dan Market Value Added (MVA) Terhadap Return Saham (Studi Pada Perusahaan Yang Terdaftar Dalam Indeks LQ45 Di Bursa Efek Indonesia Periode 2012-2016. Jurnal Riset Ilmu Administrasi Brawijaya.

Rahayu, Elok Puji. 2017. "Pengaruh EPS, RI, EVA, MVA, PER Terhadap Return Saham pada Perusahaan Manufaktur". Jurnal Ilmu dan Riset Manajemen, 6(1).

Ross, A. Stephen; Westerfield; Randolph W Jordan; Bradford D. 2003. Fundamental of Corporate Finance.

Sharif, Ilyas; Ali, Adnan; Jan, Farzan Ali, (2015). Effect of Dividend Policy on Stock Prices. Journal of Management Info, 6(1), 3(1), 2015, 56-87. https://doi.org/10.15295/bmij.v3i1.23

Thanh Duy, Nguyen; Phuoc, Nguyen Pham Huu.2016. Relationship between Firm Size and Stock Return of Service Sector Ho Chi Minh City Stock Exchange. Review of European Studies, 8(4). https://doi.org/10.5539/res.v8n4p210

Trigueiros, Duarte, 2000, A Theoritical Definition and Statistical Description of Firm Size, University of Macau, Macau. 